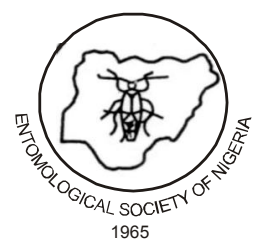

\title{
Chemical composition and Growth Rate of Blowfly Maggot from Poisoned Cadavers in Awka, Nigeria
}

\author{
Abajue, M. C. ${ }^{1 *}$ and Ewuim, S. C. ${ }^{2}$ \\ ${ }^{1}$ Department of Animal and Environmental Biology, University of Port Harcourt, Nigeria \\ ${ }^{2}$ Department of Zoology, Nnamdi Azikiwe University, Awka, Nigeria
}

\begin{abstract}
Forensic entomology is the study that uses insects found on a decomposing cadaver to estimate the time of death of the animal. However, such estimation may not be incorrect if the body was altered before or after death. One of these alterations is if the victim died of induced poison which is capable of delaying insect infestation and may therefore, increase or decrease the rate of the maggots that will be used to estimate the time of the animal's death. Therefore, a study was carried out to assess the growth rate of blowfly maggots recovered from decomposing poisoned pig cadavers. A total of 16 healthy pigs (Sus scrofa Linn.) with mean weight of $22.3 \pm 1.9 \mathrm{~kg}$ were used for the study. Eight of the pigs were sacrificed with zinc phosphide poison through their food. The remaining eight pigs were sacrificed by asphyxiation. Their bodies were deposited in a building $\left(6^{\circ} 15218.063 \mathrm{~N}\right.$ and $\left.7^{\circ} 06241.373 \mathrm{E}\right)$ and in a forest $\left(6^{\circ} 15215.323 \mathrm{~N}\right.$ and $\left.7^{\circ} 06240.223 \mathrm{E}\right)$ to mimic indoor and outdoor decompositions respectively at Awka, Anambra State, Nigeria. The effects of the rodenticide on the cadaver decomposition and growth rate of the blowfly maggots found on them were studied. The blowfly maggots collected from the poisoned and the asphyxiated pig cadavers were killed with hot water and preserved in $80 \%$ ethanol and their linear growths on daily basis measured with metre rule. Assessment of the rodenticide on the maggots recovered from the poisoned cadavers was performed with Atomic Absorption Spectrophotometer (AAS) to assess zinc and phosphorus which were the active ingredients of the poison. Analysis of variance result showed that there was significant difference between the daily mean growths of the maggots while students't-test result showed that no significant difference exists between the mean lengths of the maggots recovered from the poisoned and the asphyxiated cadavers. The AAS detected zinc only on the maggot tissues while phosphorus was not detected. The study showed that heavy metals such as zinc in rodenticides can be detected in maggots recovered from a badly decomposed cadaver. The toxicity of the rodenticide did not affect the growth rates of maggots recovered on the poisoned cadaver as compared with the maggots recovered on the asphyxiated cadaver. Other implications related to toxicological studies on cadaveric insects as a novel approach in forensic entomology and serving as alternative matrices in forensic toxicology in questionable deaths were also highlighted.
\end{abstract}

Keywords: Cadaver; rodenticide; decomposition; maggot; entomotoxicology.

\section{INTRODUCTION}

Forensic entomology is the biological study of insects associated with cadavers. The

*Correspondence author's

email:abajue.mc@gmail.com knowledge of insects found on dead bodies is becoming an integral part of forensic investigation relating to mysterious deaths because insects associated with cadavers help estimate the time when the victim died. It is an interesting aspect of entomology that can be 
studied on land and water (Keiper and Casamatta, 2001; Hobischak and Anderson, 2002). It is also evolving into entomo-toxicology, which is a critical approach in forensic toxicology that alternatively assesses presence of toxins in insects that have fed on a decomposing cadaver. Apparently, the use of insects in crime scene investigation has been well documented (Smith, 1986; Gennard, 2007) and the history was revalidated (Benecke, 2001; Greenberg and Kunich, 2002).

Toxic substances in or on a dead body may accumulate in the tissues of insect larvae while feeding on the body and may have their growth rate impaired. Hence, insects especially fly larvae (maggots) that feed on a cadaver may be suspected to retain undigested flesh from the corpse while they are still feeding on the cadaver. In some circumstances, the flesh from the corpse may retain some type of poison that had been consumed before the person died. Studies have shown that poisons can be recovered on maggots that have fed on suspicious poisoned cadavers (Introna et al., 1990). Toxicological and DNA examinations on a body in a state of advanced decomposition or a skeletonized body may be difficult to examine. This is because relevant body parts have been lost to decomposition. Hence, immature insects recovered from such body can alternatively serve as toxicological samples when the victim is suspected to die of a poisoned related issue (Introna et al., 2001; Campobasso et al., 2004). This is possible because, maggots which feed on corpse may sequester drugs and toxicants which had been ingested by the deceased person (Amendt et al., 2004). Maceration of fly maggots that have fed on poisoned cadavers prior to toxicological analysis with chromatography has been submitted as alternative substance in forensic toxicology relating to questionable deaths (Goff and Lord, 1994; Miller et al., 1994; GaglianoCandela and Aventaggiato, 2001; Bourel et al.,
2001). Till date however, information is scarce regarding the role of drugs in necrophagous insects (Gennard, 2007) but toxic substances ingested prior to death have been reported to influence the life cycle of flies especially maggots recovered on such decomposing cadaver. Muskaska et al. (2001) reported that the maggot length of flesh fly, Sarcophaga tibialis Macq that fed on liver containing either a barbiturate (sodium methohexital) or a steroid (hydrocortisone) was increased compared with the control as the pupariation was more rapid. Arnaldos et al. (2005) also performed laboratory experiments to determine the effect of heroin on the larval development of Sarcophaga tibialis Macq. and reported that the maggots development was considerately prolonged than those maggots fed without heroin while Goff et al. (1991) reported that heroin increased the rate at which the maggots of Boettohersca peregrina (Rob-Desv.) grew but prolonged the duration of the pupal development. Conversely, underestimation of postmortem interval up to 24 hours was reported when estimating the age of Lucilia sericata due to presence of morphine in maggots tissues (Bourel et al., 1999).

That drugs or poisons can be locked in the maggot tissues is therefore a heuristic report hence, determining the time and cause of death of an individual is always difficult when the body is badly decomposed and infested with insects; but still, it is an important component of coronal investigation. Therefore, there is need to study entomotoxicology because of its importance in forensic entomology which is still scarce in Nigeria. This is necessary so that when the need to use insects to estimate time of questionable death and the cause of death, the result won't be biased. Therefore, this study is geared towards using blowfly maggots recovered from decomposing poisoned and asphyxiated pig cadavers, as biological samples 
for toxicological studies. The decomposition of the cadavers and their associated maggots would be studied at two contrasting habitats. The linear growth rates of the blowfly maggots would be measured on a daily basis for a specific period of time during their growth in anticipation to use them to correlate the decomposition process of poisoned cadavers during rainy and dry seasons in Awka, Anambra State, Nigeria. The result that will be obtained is expected to add to the entomotoxicological database of Nigeria and thus, would be cued in into the global database of forensic entomology.

\section{MATERIALS AND METHODS}

\section{Study Site}

The study was carried out during the wet and dry seasons of 2014 and 2015 respectively at about $800 \mathrm{~m}$ away from the Science Village buildings, Nnamdi Azikiwe University Awka. Awka is a town located on latitude $5^{\circ}$ and $6^{\circ} 25^{\prime}$ $\mathrm{N}$ and longitude $7^{\circ} \mathrm{E}$ and $8^{\circ} \mathrm{E}$ and stretches 8 kilometers in an East-West direction along the Enugu-Onitsha expressway and about 5 kilometers in a North-South orientation. The dimension of Awka is $1,207,800 \mathrm{~m}^{2}$ or 12,007 hectares. Ecologically, Awka lies in the Guinea Savanna experiencing between 1,000 $\mathrm{mm}$ and $1,500 \mathrm{~mm}$ of rain annually (Iloeje, 1981). It also experiences two seasons; the dry and the wet seasons with a bout of harmattan between December and January. A North-South and East-West escarpment gives Awka its topographic character. Two contrasting habitats were chosen for the study at the Science Village; the Zoology garden is located at latitude $6^{\circ} 15^{\prime}$ $18.06^{\prime} \prime \prime \mathrm{N}$ and longitude $7^{\circ} 06^{\prime} 41.37^{\prime} \prime \mathrm{E}$ depicting a synanthropic environment with different levels of anthropogenic activities continually going on the garden while the forest located at latitude $6^{\circ} 15^{\prime} 15.32^{\prime \prime} ' \mathrm{~N}$ and longitude $7^{\circ} 06^{\prime} 40.22^{\prime}$ ' E depicting a serene and pristine environment. The distance between the two locations is of $300 \mathrm{~m}$ and were distinctively demarcated by a tarred road that links Science Village to Management Science, off Faculty of Social Science road (Fig. 1).

\section{Experimental Animal and Locations}

Sixteen healthy pigs, (Sus scrofa Linn.) with mean weight of $22.3 \pm 1.9 \mathrm{~kg}$, were purchased from a piggery in Okija, Anambra State for the study. The pigs were divided into two equal groups. One group was sacrificed with rodenticide (containing Zinc phosphide as the active ingredient. Each of the pigs was fed with $10 \mathrm{~g}$ of the Zinc phosphide by admixture in $500 \mathrm{~g}$ of their food to mimic food poison. The second group was sacrificed to death by asphyxiation. The dead pigs serving as human cadaver models were then left to decomposition.

The two experimental locations; the Department of Zoology garden housed a simulated building as an indoor study location and the Botany garden, a forest as an outdoor study location. The habitats were used to study the decomposition processes of the cadavers and their associated blowfly maggots. Indoor location was an erected simulated wooden hut; measuring ( $24 \mathrm{ft}$. length, $20 \mathrm{ft}$. wide and $10 \mathrm{ft}$. height) roofed with a corrugated metal sheet. The roof of the building overlapped with the erected woods with little crevice in between the roof and the woods, hence no ceiling was provided after roofing. The building was floored with concrete cement. The building has one window measuring $10 \times 10 \mathrm{~cm}^{2}$ and an entrance door measuring 8 feet height and 2 feet wide. The window remained closed throughout the study period while the door was only opened and closed at once for collection of blowfly maggots. The building housed two poisoned and two asphyxiated pig cadavers but the two groups were completely separated with a ply wood but with a connecting door. They were 


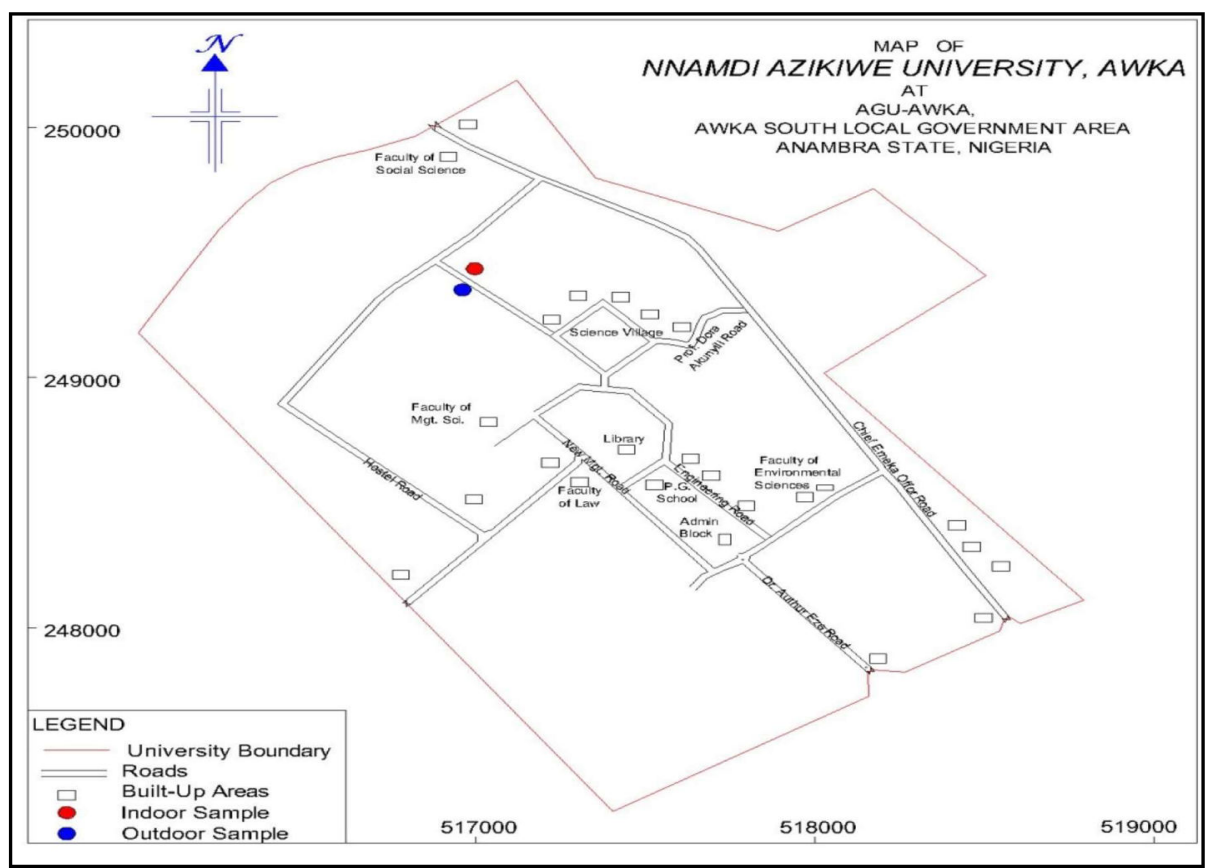

Figure 1: Map of Nnamdi Azikiwe University, Awka, Nigeria (the dots show the habitats)

simultaneously allowed to skeletonize completely during the rainy season and repeated, during the dry season. The cadavers were placed $2 \mathrm{~m}$ from each other on sacks $\left(16 \times 8 \mathrm{~cm}^{2}\right)$ that serve as mats and insects collection limit. Similar study was also carried out but at a distance of $5 \mathrm{~m}$ between the cadavers at the forest. The cadavers at the forest were protected against vertebrate scavengers with wire gauze constructed as a cage for the cadaver.

\section{Temperature, relative humidity and growth rate of the blowfly maggots}

Blowfly maggots found on the pig cadavers formed maggot mass and its temperature and the cadaver's body temperature were taken with glass rod mercury thermometer. The relative humidity and the ambient temperature of the study habitats were taken with digital thermohygrometer (Mextech TM-1, model) under a shade. Camel hair-brush was used to collect the first maggot instars. Second and third maggot instars were collected with $5 \mathrm{ml}$ spoon and a blunt forceps and were killed with hot water and preserved in $80 \%$ ethanol. The first maggot instars were cultured to adult while the lengths of second and third of the maggot instars killed with hot water were measured with a pair of compass and read on a metre rule. Samples of pupae from the cultured maggots were preserved in $70 \%$ ethanol and their lengths also measured.

\section{Assessment of Zinc phosphide (rodenticide) on the collected maggots from the pig cadavers}

Blowfly maggots on the cadavers for toxicological analysis were collected daily from Day 4 through Day 7 while the pupae samples from the cultured maggots preserved on Day 8 were collected for toxicological assessment. One gram of the maggots and pupae collected on Day 4 through Day 7 and Day 8 respectively were washed with distilled water and placed in a beaker. Then $10 \mathrm{ml}$ of $70 \%$ per Chloric acid $\left(\mathrm{HOCl}_{4}\right)$ and $10 \mathrm{ml}$ of concentrated Nitric acid $\left(\mathrm{HNO}_{3}\right)$ were added in the beaker. The content of the beaker was indirectly heated in a water bath at $60^{\circ} \mathrm{C}$ for one hour in a fume cupboard to digest the sample. After which the beaker was 
allowed to cool and $100 \mathrm{ml}$ of distilled water added in the beaker and filtered into another beaker (to prevent the acids from attacking the filter paper) during filtration. The filtered solution was then analyzed with Atomic Absorption Spectrophotometer (AAS-model: BUCK Scientific 210GP) to detect and quantify either zinc and phosphorus if they bio-accumulate in the maggots. The procedure was repeated in all the daily maggot samples collected.

\section{Data Analysis}

Numerical data (maggots length, temperature and relative humidity) were subjected to analysis of variance (ANOVA). Students't-test was used to compare the mean growth rates of the maggots from the poisoned and the asphyxiated cadavers recovered from the two habitats and between the rainy and dry seasons.

\section{RESULTS}

The decomposing pig cadavers at outdoor location was infested first with blowfly eggs before the indoor one but maggots were observed at the same time on the cadavers at the two locations. In the same trend, maggot mass was first observed at the forest on the evening of Day 3 and on the morning of Day 4 in the building. Feeding by first generation of the maggots lasted for four days in all the cadavers at both locations before dispersing for pupation. Linear growth rates of the maggots from the poisoned and the asphyxiated cadavers were the same at both locations and the rate of decomposition of the cadavers was neither influenced by the contrasting habitats nor by the method of death within a particular season. The mean of the linear lengths of the maggots collected on the decomposing cadavers on Day 3 through Day 6 during the rainy and Day 4 through Day 7 during the dry season respectively at the two contrasting habitats were presented in (Figs. 2, 3, 4 and 5). The mean of the linear growth rates of the maggots varied between the two seasons. However, the difference between the mean length of the maggots from the poisoned and asphyxiated cadavers during the two seasons and the two environments were not significant $(p>0.05)$. The pig cadavers completely decomposed and became skeletonized between 10 and 14 days during the rainy and dry seasons respectively. Assessment of zinc and phosphorus in the maggots with Atomic Absorption Spectro-photometer showed that zinc was present in the maggots recovered from the poisoned

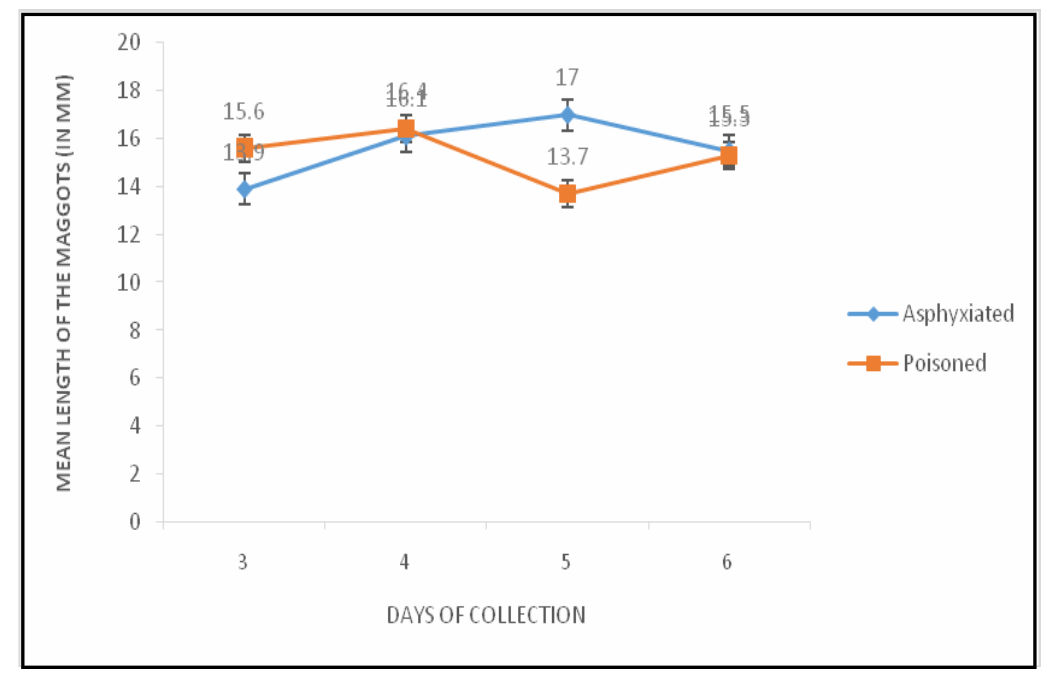

Figure 2: Mean length of the blowfly maggots (in $\mathrm{mm}$ ) recovered from the poisoned and asphyxiated pig cadavers in the forest in Awka, Nigeria during the rainy season 


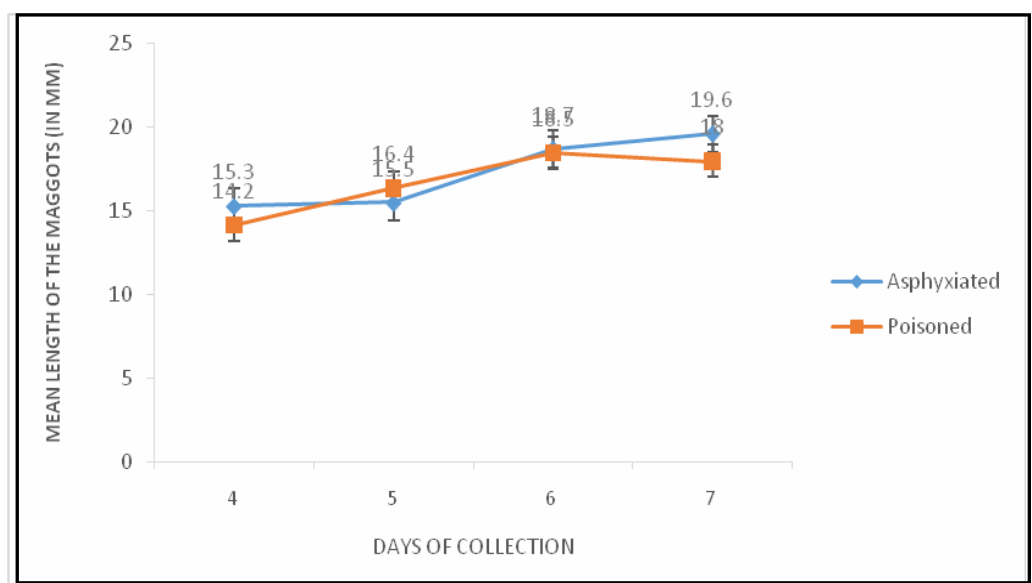

Figure 3: Mean length of the blowfly maggots (in $\mathrm{mm}$ ) recovered from the poisoned and asphyxiated pig cadavers in the building in Awka, Nigeria during the rainy reason

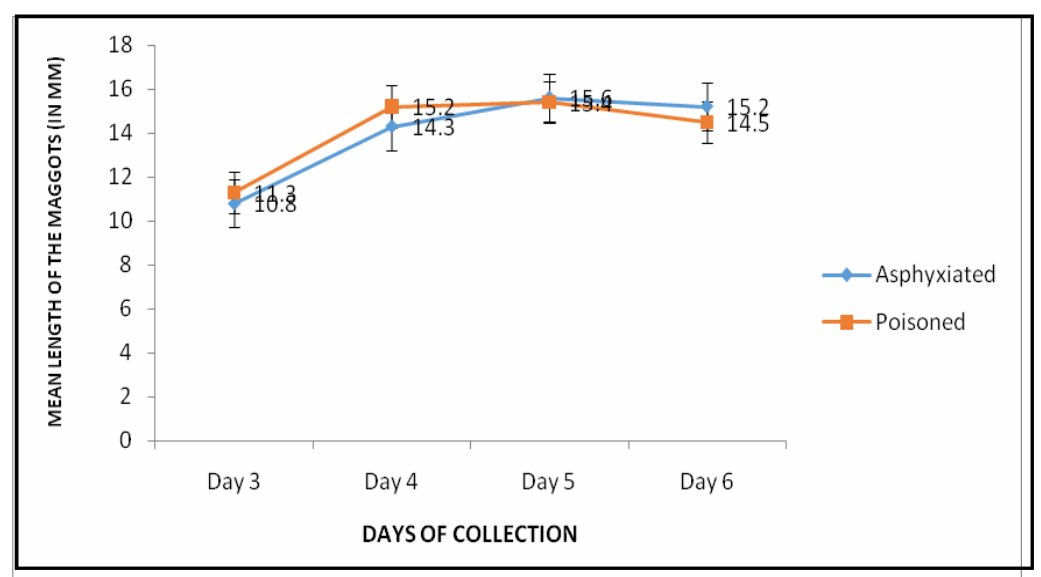

Figure 4. Mean length of the blowfly maggots (in $\mathrm{mm}$ ) recovered from the poisoned and asphyxiated pig cadavers in the forest in Awka, Nigeria during the rainy season

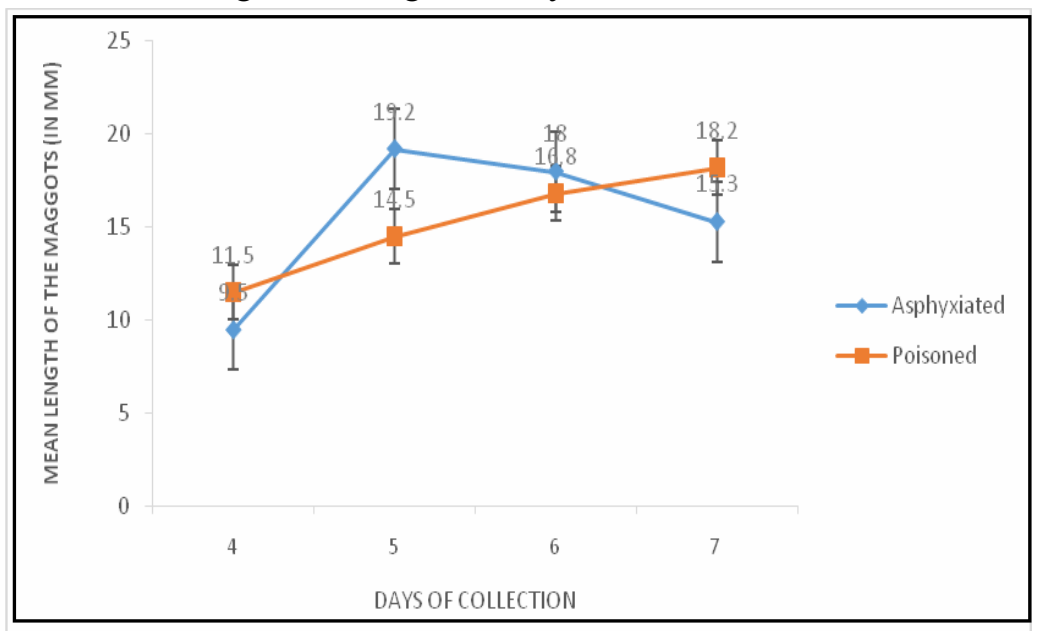

Figure 5. Mean length of the blowfly maggots $(\mathrm{mm})$ recovered from the poisoned and asphyxiated pig cadavers in the simulated building in Awka, Nigeria during the dry season 


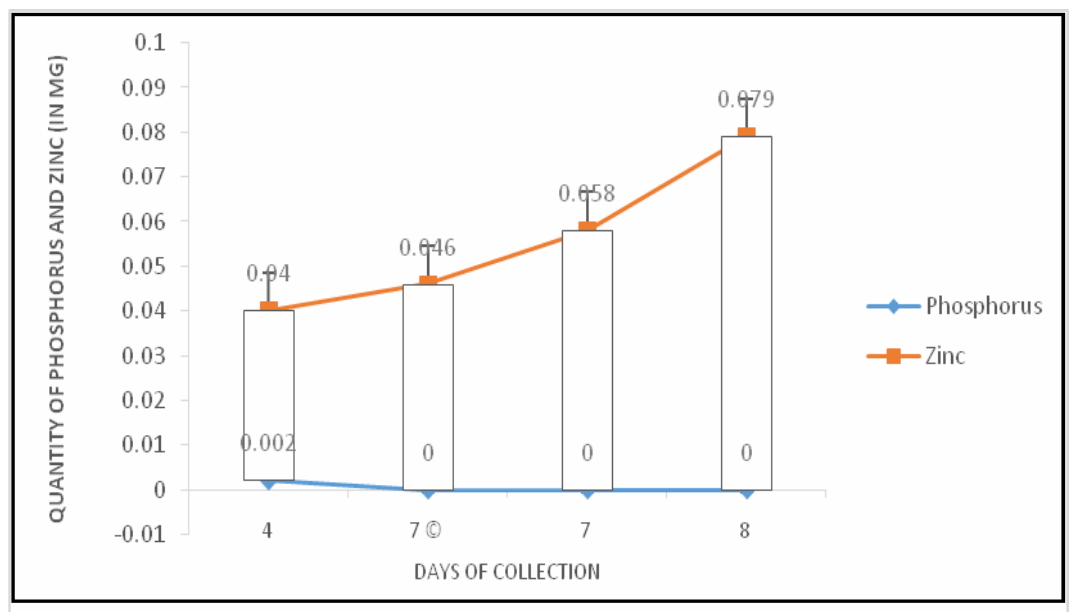

Figure 6. Quantity of phosphorus and zinc (in $\mathrm{mg}$ ) detected in the blowfly maggots using AAS Note: Day 4 and Day 7, = maggots collected from the poisoned pig cadaver, Day 7C $=$ maggots collected from the asphyxiated pig cadaver as control and Day $8,=$ pupae collected from the poisoned pig cadaver

cadavers (Fig. 6).

\section{DISCUSSION}

Cadaver tissues whether poisoned or not are consumed by necrophagous insects. Inadvertently, if the cadaver was a poisoned one it will be unavoidably consumed by insects. If the toxic substance is a synthetic one, it may metabolize in the animal's body before or immediately after death but if not metabolized, it will store in the tissues of the cadaver and bio-accumulate in insects that feed on them. Larvae that feed on a corpse may sequester drug or toxicant which was ingested by the dead person (Amendt et al., 2004) and this study affirmed the report since there was presence of zinc in the maggot that fed on the poisoned cadaver. The detection of the zinc which was one of the active ingredients of the rodenticide sold without restriction in Awka as rat poison, which killed the pigs and assessed in the blowfly maggots proved that the rodenticide is also poisonous to the pigs.

The detection of mercury in the larvae of various species of blowflies reared on tissues containing known concentrations of mercury was described by Nourteva and Nourteva, (1982). Hence, toxicological data from dipteran larvae seem to be reliable in detecting toxic substance/ poison as well as those from cadaver tissues (Kintz et al., 1990). Cocaine and its breakdown products have also been found in small quantity in the puparium of calliphorid fly(Nolte et al., 1992). Gunatilake and Goff (1989) demonstrated that malathion in the tissues of a decomposing body delayed insects colonization and oviposition for several days. This was contained in their study in a suicide case where malathion pesticide was consumed. The developmental stages of blowflies found on the dead body indicated a minimum postmortem interval of 5 days whilst the victim was last seen alive 8 days prior to the discovery of his body.

In line with previous reports, the presence of zinc though not of lethal dose and absence of phosphorus in the blowfly maggots and pupae is an indication that the phosphorus content of the rodenticide was metabolized in the pigs prior to their deaths thus, confirming Ekrakene (2012) who reported monocrotophos poison on the pupariae and adult flies recovered from monocrotophos poisoned pigs at Benin, 
Nigeria. Metabolism of some pesticides is usually rapid; hence, the zinc phosphide rapidly metabolized in the pigs hence, liberating the phosphorus into phosphine gas which caused acute kidney, lung and heart failures in the pigs thus, leading to their deaths. Phosphorus is a free radical that is not stable in the body and might have been metabolized in the maggots hence, it was not detected. The zinc on the other hand, is a heavy metal nutritionally essential in small quantity but large amount will cause acute or chronic toxicity or poisoning. Heavy metals become toxic when they are not metabolized by the body and accumulate in the soft tissues (Ezeonu, 2015).

The acute toxicity of the rodenticide which caused the death of the pigs and the zinc component which couldn't metabolize in the pigs may have led to the recovery of the zinc on the tissues of the blowfly maggots. Based on the linear growth evaluation of the maggots, the poison did not influence their growth rates while feeding on the poisoned cadavers. The insignificant growth difference observed on the maggots was due to location and seasonal differences and not due to the poison. Interestingly, the samples of the maggots cultured which later developed to adults of Chrysomya albiceps (Wied.), Chyrsomya chloropyga (Weid.) and Chysromya regalis (Rob-Desv) in the family Calliphoridae,) were among the flies reported by Abajue et al. (2013 and 2014) in Okija, Nigeria as flies of forensic importance. Ewuim and Abajue (2016) reviewed some of the blowflies as flies that were continually collected in Nigeria by her forensic entomologists. Abajue and Ewuim (2016) documented these blowflies as forensic flies associated with decomposing pig carrions in Okija which can help forensic investigators estimate the post mortem interval of questionable deaths when legally required in Nigeria. The unavoidable infestation of the cadavers by the reported blowflies with maggots via their laid eggs even at the indoor scene and on poisoned cadavers, present them as useful flies of forensic entomology and their bodies as sample for toxicological analysis in forensic toxicology of a badly decomposed corpse suspected to die of a toxic substance.

\section{CONCLUSION}

The components of the rodenticide that killed the pigs were assessed on the blowfly maggots but did not affect their growth rates and the decomposition rates of the cadavers. Decomposition difference observed was due to the two seasonal variation. Therefore, where a corpse is badly decomposed and infested with maggots and the victim suspected to die of poison, samples of blowfly maggots on the body should serve as good alternative for toxicological analysis especially when blood, urine and other vital organs are no longer useful.

\section{REFERENCES}

Abajue, M.C., Ewuim, S.C. and Akunne, C.E. (2013). Insects associated with decomposing pig carrions in Okija, Anambra State, Nigeria. The Bioscientist, (1): 54-59.

Abajue, M.C., Ewuim, S.C. and Akunne, C.E. (2014). Preliminary checklist of flies associated with pig carrions decomposition in Okija, Anambra State, Nigeria. Animal Research International, 11(1): 1899-1904.

Abajue, M.C. and Ewuim, S.C. (2016). Forensic entomology: decomposing pig carrion and its associating insects in Okija, Anambra State Nigeria. American Journal of Biology and Life Sciences, 4(2): 6-11.

Amendt, J., Krettek, R. and Zehner, R. (2004). Forensic entomology. Naturwissenschaften, 91:51-65.

Arnaldos, M.I., Garcia, M.D., Romera, E., Press, J.J. and Luna, A. (2005). Estimation of Postmortem interval in real cases based on experimentally obtained entomological evidence. Forensic Science International, 
149(1): 57-65.

Benecke, M. (2001). A brief history of forensic entomology. Forensic Science International, 120(1-2):2-14.

Bourel, B., Hedouin, V., Martin- Bonyer, L., Becart, A., Tournel, G., Deveaux, M. and Gosset, D. (1999). Effects of morphine in decomposing bodies on the development of Lucilia sericata (Diptera: Calliphoridae). Journal of Forensic Sciences, 44: 354-358.

Bourel, B., Fleurisse, L., Hedouin, V., Cailliez, J.C., Creusy C., Gosset, D. and Goff, M.L. (2001). Immunohistochemical attribution to the study of morphine metabolism in Calliphoridae larvae and implications in forensic entomotoxicology. Journal of Forensic Sciences, 46: 596-599.

Campobasso, C.P., Gherardi, M., Caligara, M., Sironi, L. and Introna, F. (2004). Drug analysis in blowfly larvae and in human tissues: a comparative study. International Journal of Legal Medicine, 118:210-214.

Ekrakene, T. (2012). Forensic entomology: When puparia of insect stages is the only link to cause. Pakistan Journal of Science and Industrial Research Services on Biological Science,55(1):51-55.

Ewuim, S.C. and Abajue, M.C. (2016). Forensic entomology: the journey so far in Nigeria. Open Science Journal of Bioscience and Bioengineering, 3(1): 1-4.

Ezeonu, F.C. (2015). Poisons in the Nigeria Environment: Within our reach, beyond our control. 25th Inaugural Lecture, Nnamdi Azikiwe University, Nigeria. Rex Charles and Patrick limited, Nimo, Anambra State, 92pp.

Gagliano-Candela, R. and Aventaggiato, $L$. (2001). The detection of toxic substances in entomological specimens. International Journal of Legal Medicine, 114: 197-203.

Gennard, D.E. (2007). Forensic entomology: An introduction. John Wiley, New York, 224Pp.

Goff, M.L., Brown, W.A., Hewadikaram, K.A. and Omori, A.I. (1991). Effects of heroin in decomposing tissues on the development rate of Boettohersca peregrine (Diptera: Sarcophagidae) and implications of this effect on postmortem intervals using arthropod development patterns. Journal of Forensic Sciences, 36: 537-542.

Goff, M.L. and Lord, W.D. (1994). Entomotoxicology: a new area of forensic investigation. American Journal of Forensic Medicine and Pathology, 15: 51-57.

Greenberg, B. and Kunich, J.C. (2002). Entomology and the Law: Flies as forensic indicators. Cambridge University Press, Cambridge.

Gunatilake, K. and Goff, M.L. (1989). Detection of organophosphate poisoning in a putrefying body by analyzing arthropod larvae. Journal of Forensic Sciences, 34:714-716.

Hobischak, N.R. and Anderson, G.S. (2002). Time of submergence using aquatic invertebrate succession and decompositional changes. Journal of Forensic sciences, 47: 142-151.

Iloeje, N.P. (1981). A new geography of Nigeria. Longman Nigeria limited, Ibadan.

Introna, F., Lo Dico, C., Coplan, Y.H. and Smialek, J.E. (1990). Opiate analysis in cadaveric blowfly larvae as an indicator of narcotic intoxication. Journal of Forensic Sciences, 35:118-122.

Introna, F., Campobasso, C.P. and Goff, M.L. (2001). Entomotoxicology. Forensic Science International, 120: 42-47.

Keiper, J.B. and Casamatta, D.A. (2001). Benthic organisms as forensic indicators. Journal of the North American Benthological Society, 20(2):311-324.

Kintz., P., Tracqui, A. and Mangin, P. (1990). Toxicology and fly larvae on a putrefied cadaver. Journal of the Forensic Science Society, 30:243-246.

Miller, M.L., Lord, W.D., Goff, M.L., Donnelly, D., McDonough, E.T. and Alexis, J.C. (1994). Isolation of amitriptyline and nortriptyline from fly pupariae (Phoridae) and beetle exuviae (Dermestidae) associated with mummified human remains. Journal of Forensic Sciences, 39:1305-1313.

Musvaska, E., Williams, K.A., Muller, W.J. 
and Villet, M.H. (2001). Preliminary observations on the effects of hydrocortisone and sodium methohexital on development of Sarcophaga (Curranea) tibialis Macquart (Diptera: Sarcophagidae), and implications for estimating postmortem interval. Forensic Science International, 125:254-261.

Nolte, K.B., Pinder, R.D. and Lord, W. D. (1992). Insect larvae used to detect cocaine poisoning in a decomposed body. Journal of
Forensic Sciences, 37: 1179-1185.

Nuorteva, P. and Nuorteva, S.L. (1982). The fate of mercury in sarcosaprophagous flies and in insects eating them. Ambio, 11:34-37.

Smith, K.G.V. (1986). A manual of forensic entomology. Trustees of the British Museum (Natural History) and Cornell University Press, London, 205pp.

Nigeria Journal of Entomology

Published by the Entomological Society of Nigeria

www.esnjournal.com.ng

ISSN: 0331-0094

Vol. 34, 2018; pp. 123-132

DOI: $10.36108 / \mathrm{NJE} / 8102 / 43(0131)$

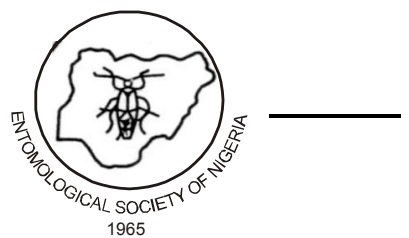

